[95\% Cl: 1.11-1.93], and neonatal septicemia: $\mathrm{HR}=1.59$ [95\% Cl: 1.21-2.10]. Generally, the increased risk of ASDs after neonatal complication was most prominent for children born preterm. Same pattern of association was found for infantile autism.

Conclusions: Different neonatal complications are likely to cause neurological damage and alter brain development, and hence increase the risk of ASDs, and infantile autism. This effect seems to be mediated through different pathways including lack of oxygen, glucose, and possibly through activated immune function during early neonatal life.

152

\section{THE INCIDENCE OF VISUALLY IMPAIRED CHILDREN CAUSED BY ROP AND THEIR CONCOMITANT DISABILITIES IN THE NETHERLANDS: A THIRTY YEAR OVERVIEW}

A. van Sorge ${ }^{1}$, J. Termote ${ }^{2}$, M. de Vries ${ }^{3}$, N. Boonstra ${ }^{4}$, N. Stellingwerf ${ }^{5}$, N. Schalij-Delfos ${ }^{1}$

${ }^{1}$ Ophthalmology, Leiden University Medical Centre, Leiden, ${ }^{2}$ Neonatology, Children's Hospital / University Medical Centre Utrecht, Utrecht, ${ }^{3}$ Ophthalomolgy, Visio: Institute for the Partially Sighted and Blind, Amsterdam, ${ }^{4}$ Ophthalomolgy, Bartimeus: Institute for the Partially Sighted and Blind, Zeist, ${ }^{5}$ Ophthalomolgy, Visio: Institute for the Partially Sighted and Blind, Haren, The Netherlands

Background/Aim: To determine the incidence of visual impairment (VI) caused by ROP in The Netherlands in infants born between 2000 and 2009 and to determine the incidence of associated disabilities. To detect changes in data, we compared our data with data of three previous comparable studies conducted between 1975-1987, 1986-1994 and 1994-2000.

Method: Data of children born between $1^{\text {st }}$ of January 2000 and 31 December 2008 were retrieved from the Dutch institutes for the partially sighted and blind. Besides ophthalmologicdata, data on behavioral abnormalities, epilepsy, hearing deficit, developmental delay, and neurological handicaps were gathered.
Results:

\begin{tabular}{|l|l|l|l|l|l|}
\hline Period & $\begin{array}{l}1975- \\
1987\end{array}$ & $\begin{array}{l}1986- \\
1994\end{array}$ & $\begin{array}{l}1994- \\
2000 \\
\text { (III) }\end{array}$ & $\begin{array}{l}2000- \\
2009 \\
\text { (IV) }\end{array}$ & $\begin{array}{l}\text { p-value } \\
\text { III vs IV }\end{array}$ \\
\hline $\begin{array}{l}\text { No.Infants } \\
\text { retrieved }\end{array}$ & 76 & 87 & 51 & 42 & \\
\hline $\begin{array}{l}\text { ROP } \\
\text { sequelae/ } \\
100.000 \\
\text { live births }\end{array}$ & 4.22 & 5.49 & 3.93 & 2.05 & 0.005 \\
\hline $\begin{array}{l}\text { Behavioral } \\
\text { abnor- } \\
\text { malities } \\
\text { and } \\
\text { problems }\end{array}$ & $9.2 \%$ & $21.8 \%$ & $46.9 \%$ & $40.0 \%$ & $n s$ \\
\hline Epilepsy & $5.3 \%$ & $6.9 \%$ & $16.3 \%$ & $0 \%$ & 0.007 \\
\hline
\end{tabular}

[Results 1]

\begin{tabular}{|l|l|l|l|l|l|}
\hline $\begin{array}{l}\text { Develop- } \\
\text { mental delay }\end{array}$ & $35.5 \%$ & $47.1 \%$ & $52.9 \%$ & $65 \%$ & ns \\
\hline $\begin{array}{l}\text { Neurological } \\
\text { handicaps }\end{array}$ & $30.3 \%$ & $49.4 \%$ & $45.1 \%$ & $42.5 \%$ & ns \\
\hline $\begin{array}{l}\text { Multiple } \\
\text { disabled }\end{array}$ & $39.5 \%$ & $58.6 \%$ & $68.2 \%$ & $73.8 \%$ & ns \\
\hline
\end{tabular}

[Results 2]

\begin{tabular}{|l|l|l|l|l|l|}
\hline $\begin{array}{l}\text { Completely } \\
\text { blind(VA = 0) }\end{array}$ & $38.4 \%$ & $26.4 \%$ & $27.5 \%$ & $7.1 \%$ & 0.012 \\
\hline $\begin{array}{l}\text { Treatment of } \\
\text { acute ROP }\end{array}$ & $24.5 \%$ & $43.9 \%$ & $56.9 \%$ & $66.7 \%$ & ns \\
\hline
\end{tabular}

[Results 3]

Conclusion: There is a decrease in the incidence of VI caused by ROP in The Netherlands. Incidence of concomitant disabilities remained the same, except for a decrease in epilepsy. There was also a decrease of completely blind children due to ROP. Still $1 / 3$ of the infants did not receive acute-phase ROP treatment.

153

\section{SOCIOECONOMIC INEQUALITIES IN NEONATAL MORTALITY: THE IMPACT OF PRETERM BIRTH ON THE WIDENING DEPRIVATION GAP}

\author{
L. Smith ${ }^{1}$, B. Manktelow ${ }^{1}$, E. Draper ${ }^{1}$, \\ A. Springett ${ }^{2}$, D. Field ${ }^{1}$ \\ ${ }^{1}$ Health Sciences, University of Leicester, \\ Leicester, ${ }^{2}$ CMACE, London, UK
}

Backgroundandaims: Socio-economicinequalities in neonatal mortality exist within many developed 